Michael Blamauer (Ed.)

The Mental as Fundamental

New Perspectives on Panpsychism 

Michael Blamauer (Ed.)

\section{The Mental as Fundamental}

New Perspectives on Panpsychism

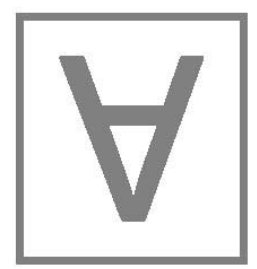

ontos

verlag 
Bibliographic information published by Deutsche Nationalbibliothek

The Deutsche Nastionalbibliothek lists this publication in the Deutsche Nationalbibliographie; detailed bibliographic data is available in the Internet at http://dnb.ddb.de

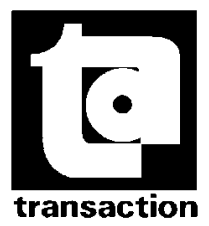

North and South America by

Transaction Books

Rutgers University

Piscataway, NJ 08854-8042

trans@transactionpub.com

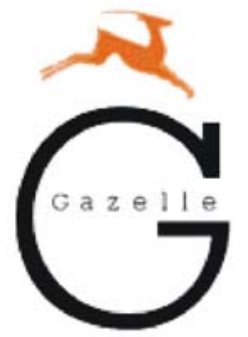

United Kingdom, Ire, Iceland, Turkey, Malta, Portugal by

Gazelle Books Services Limited

White Cross Mills

Hightown

LANCASTER, LA1 4XS

sales@gazellebooks.co.uk

Livraison pour la France et la Belgique:

Librairie Philosophique J.Vrin

6 , place de la Sorbonne ; F-75005 PARIS

Tel. +33 (0)1 43540347 ; Fax +33 (0)1 43544818

www.vrin.fr

(C)2011 ontos verlag

P.O. Box 15 41, D-63133 Heusenstamm

www.ontosverlag.com

ISBN 978-3-86838-114-6

2011

No part of this book may be reproduced, stored in retrieval systems or transmitted

in any form or by any means, electronic, mechanical, photocopying, microfilming, recording or otherwise without written permission from the Publisher, with the exception of any material supplied specifically for the purpose of being entered and executed on a computer system, for exclusive use of the purchaser of the work

Printed on acid-free paper

ISO-Norm 970-6

FSC-certified (Forest Stewardship Council)

This hardcover binding meets the International Library standard

Printed in Germany

by CPI buch bücher.de 